\title{
HISTORYCZNE PRZESŁANKI KSZTAŁTOWANIA SIE POLSKIEJ KULTURY ORGANIZACYJNEJ ORAZ JEJ WSPÓŁCZESNE MANIFESTACJE W POSTAWACH I DOZNANIACH PSYCHICZNYCH
}

\begin{abstract}
Hryniewicz Janusz T., Historyczne przestanki ksztattowania się polskiej kultury organizacyjnej oraz jej wspótczesne manifestacje w postawach i doznaniach psychicznych [Historical premises of shaping Polish organizational culture and its contemporary manifestation in psychical experiences and attitudes] edited by W. Banach - "Człowiek i Społeczeństwo”, vol. XXXVIII, Poznań 2014, pp. 11-31, Adam Mickiewicz University Press. ISBN 978-83-232-2791-5. ISSN 0239-3271.

The aims of the paper are: 1. Description (of the place) of Poland in the context of the economic and cultural divisions of the European space. 2. Checking if the hitherto divisions of European space are still important. In this context, the cultural division of European space is analyzed in cross - Catholic and Protestant - cultural circles. Economic division was initiated in the XVI century and divided Europe into two parts. In the first of them (Western Europe) capitalism was initialized. In the second the East European economic system has emerged. This economic system was based on agriculture and its key institution was the manor farm. The Polish organizational culture is an effect of participation in: the Catholic cultural circle and East European economic system. Contemporary researches show that the manor farm tradition is still in existence in the attitudes of workers and managers alike.

Janusz T. Hryniewicz, Uniwersytet Warszawski, Studium Europejskich Studiów Regionalnych i Lokalnych (EUROREG), ul. Krakowskie Przedmieście 30, 00-927 Warszawa, Poland.
\end{abstract}

\section{METODY ANALIZY}

Współcześni badacze utożsamiają kulturę z przedmiotami ideowymi znaczącymi dla kształtowania się zachowań społecznych. I tak na przykład w badaniach nad różnicami pomiędzy narodowymi kulturami organizacyjnymi kulturę zdefiniowano jako „zbiorowe zaprogramowanie umysłu, które odróżnia członków jednej grupy lub kategorii osób od członków innej"1. Ujednolicanie zachowań w ramach jednej kultury dokonuje się na podstawie

${ }^{1}$ G. Hofstede, Kultury i organizacje, przeł. M. Durska, PWE, Warszawa 2000, s. 375. 
wzorów zachowań i wartości² albo norm mówiących, jak należy postępować3. Wzory zachowań to modele informujące, jakich zachowań oczekuje się od osobnika zajmującego daną pozycję społeczną w określonej sytuacji. Wartości natomiast to przedmioty materialne lub ideowe uznawane za godne pożądania, których brak na gruncie danej kultury odczuwany jest jako frustracja; wymienić tu można np. pieniądze, uczciwość, godność, wolność, przedsiębiorczość, gospodarność itp. Zastanówmy się teraz, gdzie wśród tych wszystkich wzorów i wartości należy szukać kultury organizacyjnej. Będzie ona utożsamiana z wartościami, wzorami, instytucjami, które regulują współdziałanie ludzi w trakcie pracy. Na potrzeby dalszych rozważań przyjmę, że instytucje to kulturowo utrwalone metody regulacji ram dla zachowań zbiorowych w sferze gospodarczej, politycznej i w życiu codziennym. Ramy instytucjonalne mogą pozwalać na większą lub mniejszą swobodę $\mathrm{w}$ doborze zachowań. Instytucje dzielimy na formalne (np. prawo własności, umowa cywilna) i nieformalne (np. narzeczeństwo, gościnność itp.). Szczególnym przypadkiem instytucji są organizacje. Kultura organizacyjna jest elementem szerszego kompleksu zjawisk, który możemy określić mianem kultury gospodarczej. Dość często oba te terminy są używane zamiennie. Podobnie będzie w niniejszym opracowaniu. U źródeł tego uproszczenia leży wygoda stylistyczna.

Analiza europejskich zróżnicowań kulturowych będzie obejmowała dwa wymiary: instytucjonalny i ideowy. Wymiar instytucjonalny dotyczy relacji między podstawowymi instytucjami gospodarczymi i politycznymi. Zakłada się, że instytucje gospodarcze i polityczne są podstawą długofalowego kształtowania się wzorów i wartości kulturowych. Sposób wnioskowania jest tu następujący: najpierw pojawiają się interesy, czyli korzystne stany rzeczy (np. dla szlachty wschodnioeuropejskiej w XVI wieku korzystny był eksport zboża), potem pojawiają się instytucje relatywnie najlepiej służące tym interesom (np. folwark) i instytucje polityczne podtrzymujące określoną (np. folwarczną) metodę gospodarowania. Na bazie utrwalonych instytucji tworzą się specyficzne wzory zachowań i wartości. Najpierw gospodarka, potem kultura. Drugi wymiar analizy różnic kulturowych odwołuje się do idei i koncentruje na wykryciu odmiennych zależności. Bywa tak, że pojawienie się zmian w obrębie kultury skutkuje upowszechnieniem się nowych instytucji gospodarczych. Jednym z elementów kultury jest religia. Zmiana religijna polegająca na pojawieniu się protestantyzmu zaowocowała upo-

2 T. Parsons, The Social System, Free Press, New York 1951, s. 15 i 46; A. Kłoskowska, Socjologia kultury, PWN, Warszawa 1983, s. 214, 229; R. Benedict, Wzory kultury, przeł. J. Prokopiuk, PWN, Warszawa 1966, s. 67-116.

${ }^{3}$ F. Znaniecki, Nauki o kulturze, PWN, Warszawa 1971, s. 468-538. 
wszechnieniem instytucji kapitalistycznych. Najpierw kultura, potem gospodarka. $\mathrm{W}$ trakcie dalszych analiz pokażemy, w jaki sposób podział na katolicki i protestancki krąg kulturowy wiąże się z różnicami w zachowaniach. Analiza związku doznań psychicznych z kulturą organizacyjną będzie się odnosiła do dwóch założeń: (1) że dokonania cywilizacyjne i wysoka sprawność instytucji sprawiają, iż potrzeby ludzi są lepiej zaspokajane, a wtedy ich dobrostan psychiczny jest relatywnie większy, oraz (2) że kultury narodowe różnią się poziomem dopasowania do wymogów nowoczesnej gospodarki rynkowej, zaś uczestnicy kultur słabiej dopasowanych są zmuszeni podjąć namysł i dyskusję nad zmianami na rzecz dopasowania, co wymaga nakładów energii psychicznej i relatywnie zmniejsza dobrostan psychiczny.

\section{PROTESTANCI I KATOLICY - RÓŻNICE POSTAW SPOLECZNO-POLITYCZNYCH}

Wraz z ugruntowaniem się podziału Europy na część katolicką i protestancką oraz po politycznym usankcjonowaniu (w 1648 roku) tych różnic utrwalał się również kulturowy podział Europy. Można przyjąć, że szczególnie dużą rolę $\mathrm{w}$ dyferencjacji kultury europejskiej odegrały procesy związane z umocnieniem się kapitalizmu, które grosso modo doprowadziły do przeciwstawienia kultury mieszczańskiej i protestanckiej kulturze katolickiej i szlacheckiej. Jest to podział niezależny od podziału kulturowego i gospodarczego na Europę Wschodnią i Zachodnią. Już Max Weber zauważył różnice osiągnięć gospodarczych obu tych kręgów kulturowych. Są one nadal dość wyraźne. Nieco później Émile Durkheim zwrócił uwagę na społeczno-kulturowe różnice między środowiskami katolickimi i protestanckimi, którym towarzyszyły różnice w komforcie psychicznym. W wydanej w 1982 roku pracy D. Tracy' ego ${ }^{4}$ znajdujemy opis różnic osobowościowych dotyczących sposobu postrzegania rzeczywistości społecznej przez protestantów i katolików. Kamieniem węgielnym tych różnic jest fakt, że dominujący w każdym z tych wyznań pogląd o relacji między Bogiem a światem ludzkim jest odmienny i inaczej profiluje skłonności poznawcze i wartościujące. Przekonania te fundują coś w rodzaju świadomości pierwotnej (preconscious), która nadaje znaczenie światu zewnętrznemu i tym samym narzuca sposoby postępowania. Opisana wyżej koncepcja została przyjęta przez innych autorów i rozwinięta tak, by mogła być stosowana $\mathrm{w}$ toku masowych

${ }^{4}$ D. Tracy, Analogical Imagination, The Crossroad Publishing Company, New York 1982. 
badań empirycznych - posłużyła do zaprojektowania badań przeprowadzonych w latach 1981-1986 w trzydziestu krajach. Zaprezentowane dalej informacje oparte są na wynikach badań realizowanych $w$ pięciu krajach anglojęzycznych (Irlandii, Stanach Zjednoczonych, Wielkiej Brytanii, Kanadzie i Australii), zaś niektóre wnioski oparte są również na wynikach badań z innych krajów, np. RFN czy Holandii ${ }^{5}$.

Interesującym rezultatem tych badań było niepotwierdzenie się hipotezy zaczerpniętej od Maxa Webera, a dotyczącej różnic w zakresie etyki pracy i aspiracji związanych z kształceniem między katolikami a protestantami. Potwierdziły się natomiast oczekiwania dotyczące różnych sposobów postrzegania instytucji społecznych przez katolików i protestantów. Mianowicie, w miejscu pracy katolicy akcentują priorytetowe znaczenie takich wartości, jak sprawiedliwość i równość, natomiast protestanci - wolności i indywidualizmu. Katolicy słabiej respektują porządek, którego nie rozumieją, i bardziej od protestantów są skłonni domagać się równej płacy za tę samą pracę. Co interesujące, katolicy $\mathrm{w}$ relatywnie mniejszym stopniu aprobują prawa właściciela do zarządzania firmą, zwłaszcza wtedy gdy stoją one w sprzeczności z innymi wartościami, takimi jak np. sprawiedliwość. W środowiskach katolickich równość jest wyraźnie wyżej ceniona niż wolność. Generalnie rzecz biorąc, katolicy charakteryzują się większą tolerancją polityczną dla lewicowego i prawicowego ekstremizmu, natomiast ostrzej od protestantów oceniają zachowania podważające więź społeczną w mikrogrupie i społeczeństwie, takie jak: samobójstwo, aborcja, eutanazja czy zdrada małżeńska. Protestanci z kolei silniej akcentują indywidualną odpowiedzialność i ostrzej od katolików oceniają łapówki i kłamstwa. Wobec prawa protestanci są bardziej posłuszni i bardziej skłonni do stosowania aresztu. Ponadto są przekonani, że państwo nad nimi dominuje i że brak im mocy do obrony przed tą dominacją. Natomiast katolicy są mniej posłuszni prawu, w większym stopniu są skłonni aprobować protesty z użyciem siły, a także $\mathrm{w}$ większym stopniu są przekonani o konieczności podwyższenia statusu kobiet. Do państwa katolicy mają stosunek bardziej pozytywny i w relatywnie większym stopniu aprobują interwencjonizm państwowy i politykę egalitaryzacji dochodów. W życiu codziennym są bardziej towarzyscy i silniej związani z rodziną i społecznością lokalną. Widać więc wyraźnie, że potwierdziła się hipoteza mówiąca o tym, iż katolicy postrzegają społeczeństwo jako raczej popierające jednostkę, natomiast protestanci raczej $\mathrm{w}$ kategoriach opresji i wrogości. Oznacza to, że przynależność religijna znacząco wiąże się z wartościami i postawami i że różnice w tym zakresie są względnie trwałe oraz

${ }^{5}$ A. Greeley, Protestant and Catholic: Is the Analogical Imagination Extinct?, „American Sociological Review" 1989, no. 54(4). 
niezależne od wieku i pozycji społecznej. Chociaż w sprawach bardziej szczegółowych, np. popierania konkretnej partii politycznej, zauważalne są fluktuacje wskazujące na zlaicyzowanie tych decyzji, to jednak różnice nadal się utrzymują. Świadczą o tym rezultaty badań holenderskich dotyczących długofalowych (w latach 1964-1992) trendów w zakresie związku między przynależnością religijną: katolicką i kalwińską, oraz bezwyznaniowością a popieraniem partii politycznych. Okazało się, że wpływ afiliacji religijnej malał dość wyraźnie, a największy spadek wystąpił w latach sześćdziesiątych i siedemdziesiątych. W połowie lat siedemdziesiątych tempo spadku zmniejszyło się, a w latach osiemdziesiątych wygasło. Różnice, chociaż mniejsze, nadal są względnie wyraźne ${ }^{6}$.

W obu tych kręgach kulturowych instytucje i systemy wartości w taki sposób regulują zachowania jednostek, że dążą one do zaspokojenia nieco odmiennych potrzeb. W protestanckim kręgu kulturowym na plan pierwszy wysuwają się potrzeby materialne, autonomii i osiągnięć indywidualnych. $\mathrm{Z}$ kolei $\mathrm{w}$ środowisku katolickim relatywnie silniej akcentowane są potrzeby bezpieczeństwa i afiliacyjne (przynależności, szacunku, miłości). Oczywiście, wszyscy ludzie per saldo mają takie same potrzeby, a owe różnice wskazują tylko na inne rozłożenie priorytetów w omawianym zakresie. Odmienne orientacje $w$ odniesieniu do priorytetów życia codziennego doprowadziły do tego, że w efekcie codziennych zachowań masowych instytucje, systemy wartości i wzory zachowań utrwalały się w taki sposób, aby ułatwiać zaspokajanie priorytetowych potrzeb i utrwalać te zachowania w przyszłych pokoleniach. W efekcie protestanckie instytucje lepiej służą osiąganiu dobrobytu materialnego, zaś katolickie komfortu psychicznego.

Zastanówmy się teraz nad syntetyczną oceną opisanych wyżej różnic. I tak na plan pierwszy wysuwa się kolektywizm katolicki przeciwstawiony protestanckiemu indywidualizmowi. Wiąże się to $\mathrm{z}$ relatywną zamkniętością kręgów rodzinnych i brakiem skłonności do ponadrodzinnego współdziałania $\mathrm{w}$ tej pierwszej grupie. Z kolei relatywny katolicki antyintelektualizm wiąże się $\mathrm{z}$ substancjalnym raczej niż uniwersalnym sposobem postrzegania świata, co wyraża się w przekonaniu, że uniwersalia, takie jak sprawiedliwość, uczciwość, wolność, tylko wtedy są priorytetami, gdy przynoszą dobro konkretnej wspólnocie. Na zakończenie odnotujmy mniejszy rygoryzm moralny i polityczny środowisk katolickich $\mathrm{w}$ porównaniu $\mathrm{z}$ protestanckimi.

${ }^{6}$ R. Eisenga, A. Felling, J. Lammers, Religious Affiliation, Income Stratification and Political Party Preference in Netherlands 1964 to 1992, "The Netherlands Journal of Social Sciences" 1994, vol. 30 , no. 2 . 


\section{SPECYFIKA WSCHODNIOEUROPEJSKIEGO KOMPLEKSU GOSPODARCZEGO}

Różnice rozwoju gospodarczego między wschodem i zachodem Europy były widoczne już w średniowieczu, a później jeszcze bardziej się pogłębiły. Zobaczmy, w jaki sposób to przebiegało. W XVI wieku na zachodzie Europy zaczął rosnąć popyt na zboże, co spowodowane było wzrostem liczebności ludności miejskiej w tej części kontynentu. W krajach położonych na wschód od Łaby możliwość zwiększenia dochodu drogą eksportu zboża stała się silnym bodźcem skłaniającym do restrukturyzacji gospodarstw szlacheckich nakierowanej na specjalizację $\mathrm{w}$ produkcji roślinnej i wzrost ilościowy produkcji. Dążenie do zwiększenia produkcji realizowano poprzez odwrót od pieniężnego spłacania powinności feudalnych na rzecz przymusowego świadczenia pracy przez chłopów, rozbudowanie szlacheckich praw do ziemi kosztem praw chłopskich oraz wtórne poddaństwo polegające na zespoleniu poddaństwa osobistego, gruntowego i sądowego. $Z$ zespoleniem poddaństwa szła $\mathrm{w}$ parze koncentracja uprawnień do dysponowania chłopem i jego ziemią oraz przyznanie właścicielowi folwarku uprawnień sądowych wobec chłopów. Na zachodzie Europy, np. w zachodnich Niemczech, uprawnienia te były rozdzielone i mogły znajdować się w różnych rękach; zdarzało się nawet, że uprawnienia sądowe wobec chłopów miał innych chłop. O ile stosunki poddaństwa na wschód od Łaby regulowało głównie prawo zwyczajowe, o tyle $\mathrm{w}$ zachodniej części Niemiec stosowano prawo rzymskie, prawo prywatne i prawo sądowe ${ }^{7}$. Restytucji poddaństwa towarzyszyło stopniowe ograniczanie dostępu chłopów do rynku i wzrost znaczenia świadczeń rzeczowych, a także odseparowanie chłopów od państwa polegające na zaniku obciążeń podatkami państwowymi i wzroście świadczeń na rzecz właściciela wsi ${ }^{8}$. Ten typ rozwoju cechował m.in. Niemcy Wschodnie (od linii Łaby), Polskę, Chorwację, Czechy i Rosję̧.

Do czasu pojawienia się dualizmu gospodarczego w Europie podział na część wschodnią i zachodnią był widoczny, ale nie miał charakteru tak daleko idących odmienności instytucjonalnych i społecznych. Jak wynika z badań J. Kłoczowskiego, średniowieczna środkowo-wschodnia Europa rozwijała się poprzez import kulturowy z zachodu i nieco wolniej wdrażała innowacje gospodarcze i administracyjne. W Europie wschodniej można było zaobser-

7 J. Rutkowski, Wieś europejska późnego feudalizmu (XVI-XVIII w.), wybór i wstęp J. Topolski, PIW, Warszawa 1986, s. 41; B. Geremek, K. Piesowicz, Ludzie, towary, pieniądze, Wiedza Powszechna, Warszawa 1968, s. 179.

8 J. Rutkowski, op. cit., s. 19.

${ }_{9}$ B. Geremek, K. Piesowicz, op. cit., s. 189. 
wować odpowiedniki tych samych instytucji gospodarczych i politycznych, które były na zachodzie, w mniej więcej podobnym kształcie ${ }^{10}$. Podobne oceny znajdujemy $\mathrm{u}$ niektórych autorów niemieckich ${ }^{11}$. Powstanie wschodnioeuropejskiego kompleksu gospodarczego miało charakter głębokiej restrukturyzacji gospodarczej, której towarzyszyły równie głębokie zmiany polityczne i kulturowe. Utrwalenie się wschodnioeuropejskiego kompleksu gospodarczego spowodowało trwały podział Europy na dwa jakościowo odmienne systemy gospodarcze oraz związane z tym odmienności społeczne i polityczne. Najważniejszą, niewątpliwie, instytucją gospodarczą istniejącą w ramach wschodnioeuropejskiego kompleksu gospodarczego był folwark, który ukształtował się w XVI wieku. Folwarczna kultura organizacyjna doprowadziła do utrwalenia dwóch odmiennych typów zachowań: pracowników i kierownictwa folwarku. Po stronie właścicieli-kierowników miała miejsce pełnia nieskrępowanej władzy i świadomość całkowitej dowolności decyzyjnej, natomiast po stronie chłopów wykształcił się etos wymuszonego lub zinternalizowanego posłuszeństwa połączony z brakiem poczucia odpowiedzialności oraz zapotrzebowaniem na szczegółowe instrukcje $\mathrm{w}$ pracy i opiekę ze strony kierownika poza pracą. Wyrazem trwałości tego etosu w środowisku chłopskim były dość częste negatywne reakcje chłopów na propozycje zniesienia pańszczyzny i poszerzania gospodarstw chłopskich; w XVIII wieku chłopi woleli być wyrobnikami niż samodzielnymi gospodarzami ${ }^{12}$. Mamy tu do czynienia ze zjawiskiem podobnym do opisanej w XX wieku przez Ericha Fromma „ucieczki od wolności”. W tym przypadku jest to ucieczka od ryzykownej i frustrującej wolności oraz wysiłku intelektualnego w komfort psychiczny poddaństwa.

Historyczny transfer kultury folwarcznej do współczesności był w Polsce ułatwiony dzięki antykapitalistycznemu nastawieniu kultury literackiej. Kultura folwarczna ukształtowała nie tylko styl kierowania, ale także sposób reagowania na polecenia. Ukształtowała zatem w równym stopniu kierowników, jak i pracowników. Jakie jest poznawcze znaczenie informacji o folwarcznych korzeniach polskiej kultury organizacyjnej? Względna trwałość folwarcznych wzorów zachowań tłumaczy zapóźnienie gospodarcze Polski wobec innych krajów europejskich, które doświadczyły odmiennej historii gospodarczej i mają inną tradycję kulturową. W Europie gospodarka folwarczna i właściwa jej kultura organizacyjna powstały na wschód od Łaby. Kiedy we wschodniej części Europy tworzyła się gospodarka folwarczna,

${ }^{10}$ Zob. J. Kłoczowski, Młodsza Europa, PIW, Warszawa 1998.

11 Zob. H. Boockmann, Zakon Krzyżacki, przeł. R. Traba, Wydawnictwo MARABUT, Oficyna Wydawnicza VOLUMEN, Gdańsk-Warszawa 2002, s. 87.

${ }^{12}$ J. Rutkowski, op. cit., s. 86. 
w zachodniej części kontynentu, zwłaszcza w krajach protestanckich, formowały się instytucje kapitalistyczne i towarzysząca im rynkowa kultura organizacyjna. Współcześnie nadal mamy do czynienia z przenikaniem się w polskiej kulturze organizacyjnej wzorów folwarcznych i wzorów właściwych dla kultury rynkowej.

Folwark jako kluczowa instytucja gospodarcza spowodował upodobnienie się stosunków gospodarczych w krajach leżących na wschód od Łaby, poczynając od Prus, kończąc na Rosji, a w stronę południa Europy, poprzez Czechy i Węgry, sięgając Chorwacji. Niezbywalne cechy tego sposobu produkcji to duży dystans między kierownikiem-właścicielem a pracownikami wykonawczymi, bardzo silna solidarność pracowników skierowana przeciwko kierownictwu, kolektywizm i relatywizm etyczny (kradzież w grupie własnej jest dolegliwie karana, ukraść coś właścicielowi - nie grzech) ${ }^{13}$.

Analizę wspólnych cech wschodnioeuropejskiej kultury organizacyjnej w kategoriach dziedzictwa wzorów po gospodarce folwarcznej komplikuje fakt przynależności niektórych społeczeństw do bizantyńskiego kręgu kulturowego. Dla pewnej grupy badaczy ${ }^{14}$ granica zasięgu religii katolickiej i prawosławnej jest równoznaczna z granicą cywilizacyjną. Odmienne stanowisko w tej sprawie zajmują węgierscy autorzy: Konrad i Szelenyi. Ich zdaniem w Europie Wschodniej można wyróżnić dwa kompleksy: ortodoksyjny - Rosja, Rumunia, Serbia, Bułgaria, oraz „uzachodniony” - pozostałe kraje leżące na wschód od Łaby. Kompleks ortodoksyjny cechuje bardzo wyraźna dominacja urzędu nad własnością oraz dość silne, zwłaszcza w Rosji, dziedzictwo azjatyckiego sposobu produkcji. W części „uzachodnionej" mamy do czynienia z relatywnie większą rolą rynku i miast oraz silniejszymi zachodnimi wpływami kulturowymi, takimi jak katolicyzm czy protestantyzm ${ }^{15}$. Niezależnie od tych różnic w całej Europie Wschodniej, łącznie z Prusami i Austrią, zaistniały sprzyjające warunki do wyodrębnienia się dwóch grup dominujących, tj. biurokratów kontrolujących urzędy i gospodarkę oraz wyraźnie słabszej burżuazji. Stopniowo, do XX wieku, pozycje biurokratyczne zmonopolizowała inteligencja, $\mathrm{z}$ właściwym sobie etosem klasowym i zawodowym. Jego osobliwością było przekonanie, że cele zawodowe i życiowe osiąga się via urząd, a nie via rynek, tak jak to miało miejsce $\mathrm{w}$ przypadku zachodnioeuropejskich professionals. Towarzyszy temu dość silnie ugruntowane przekonanie, iż lepiej jest alokować zasoby

13 Zob. S. Bystroń, Kultura ludowa, Nasza Księgarnia, Warszawa 1936.

14 Zob. S. Huntington, Zderzenie cywilizacji i nowy ksztatt tadu światowego, przeł. H. Jankowska, MUZA SA, Warszawa 1997.

${ }^{15}$ G. Konrad, I. Szelenyi, The Intellectuals on the Road to Class Power, New York-London 1979 , s. 25, 41, 115. 
poprzez planowanie realizowane przez urzędy, niż polegać na nieprzewidywalnym i anarchicznym rynku. Taki sposób zarządzania państwem autorzy węgierscy określają mianem racjonalnego redystrybucjonizmu ${ }^{16}$. Jak widać, Konrad i Szelenyi mówią o dużym podobieństwie instytucji politycznych, gospodarczych i postaw w krajach wschodnioeuropejskich. Natomiast cytowany wcześniej Huntington jest zwolennikiem tezy, że między ortodoksyjnym a „uzachodnionym” kompleksem więcej jest różnic niż podobieństw. Trzeba przyznać, iż stanowisko Huntingtona jest bardziej zgodne ze współczesną granicą afiliacji politycznych państw wschodniej Europy. Natomiast gdy rozważamy długofalowe kształtowanie się tendencji w zakresie kultury gospodarczej i politycznej, rację należy przyznać autorom węgierskim.

Jak się ma wschodnioeuropejskość do opisanego wcześniej zróżnicowania na katolicki i protestancki krąg kulturowy? Wschodnioeuropejskość i katolickość są źródłem bodźców o podobnym ukierunkowaniu. W przypadku niektórych krajów Europy Wschodniej katolickość i wschodnioeuropejskość nakładają się na siebie, tworząc względnie spójny system wzorów kulturowych i orientacji osobowościowych. Spróbujmy je krótko zaprezentować. Katolicką spuścizną jest prymat potrzeb afiliacyjnych nad samorealizacją i potrzebą osiągnięć. Prowadzi to do zdecydowanego kolektywizmu manifestującego się głównie w postaci silnej solidarności rodzinno-koleżeńskiej, czemu towarzyszy duży nacisk na więzi emocjonalne (takie jak w rodzinie) w miejscu pracy i działalności publicznej. Prymat więzi społecznych nad normami uniwersalnymi, takimi jak np. uczciwość, sprawia, że inne grupy rodzinne i instytucje publiczne jawią się jako obce i wrogie. Stąd też zewnętrzni obserwatorzy piszą o indywidualizmie Polaków, podczas gdy w rzeczywistości jest to następstwo chaosu życia codziennego wynikającego z konformizmu wobec własnej grupy i nieufności wobec wszystkiego, co nią nie jest. Sarmackim dziedzictwem jest silny nacisk na egalitaryzm w grupie własnej z jednoczesnym mocnym poczuciem wyższości wobec ludzi i grup o mniejszej władzy. I tak na przykład $z$ badań w trzynastu miastach wynika, że kierownicy wyższego szczebla wobec podległych sobie innych kierowników stosują demokratyczny styl kierowania, natomiast wobec wykonawców stosowany jest styl autokratyczny ${ }^{17}$. Wzmacnia to folwarczną spuściznę polegającą na bierności i unikaniu intelektualnego angażowania się $\mathrm{w}$ pracę.

16 Ibidem.

${ }_{17}$ Zob. J.T. Hryniewicz, Stosunki pracy w polskich organizacjach, Wydawnictwo Naukowe Scholar, Warszawa 2007. 


\section{POLSKA KULTURA ORGANIZACYJNA W MIĘDZYNARODOWYM KONTEKŚCIE}

Spróbujmy teraz ustalić osobliwości polskiej kultury organizacyjnej na tle Stanów Zjednoczonych i Europy. Dotychczasowe badania nad tzw. europejskim stylem zarządzania ograniczały się do państw Europy Zachodniej. Wynika z nich, że mimo narodowych różnic da się znaleźć takie cechy, które różnią zarządzanie europejskie od amerykańskiego. Kierowanie w Stanach Zjednoczonych cechuje skrupulatne stosowanie technik zarządzania nauczanych na uczelniach, podczas gdy w Europie traktuje się je jako punkt wyjścia. Kierowników amerykańskich charakteryzuje zdyscyplinowane i ustrukturowane myślenie. Bardzo dobrym przykładem takiego podejścia jest znany w Polsce podręcznik zarządzania napisany przez Stonera i Wankela ${ }^{18}$. Lektura podręcznika pozwala odnieść wrażenie, że jego zawartość to nic innego jak zastosowanie zasad logiki formalnej do analizy zachowań kierowniczych i sposobu myślenia o organizacji. Amerykańscy kierownicy dążą do przełożenia prognoz na wielowariantowe instrukcje, procedury itp. Każde ważniejsze przyszłe zdarzenie powinno być przeanalizowane $\mathrm{w}$ taki sposób, aby w przypadku jego zajścia można było do niego dopasować jedną z opracowanych wcześniej recept. Towarzyszy temu przekonanie, iż da się wykryć uniwersalne zasady zarządzania mające zastosowanie do kierowania wszelką działalnością gospodarczą, niezależnie od branży czy sektora. W Europie panuje pogląd, że powinno się znać specyfikę danej branży, aby dobrze nią zarządzać. Europejski styl zarządzania cechuje intuicjonizm, większa wrażliwość społeczna $\mathrm{w}$ znaczeniu nastawienia na zaspokojenie potrzeb afiliacyjnych i uczestnictwa $w$ decyzjach. Intuicjonizm $\mathrm{z}$ natury rzeczy jest raczej partykularny niż uniwersalny. W firmach europejskich zarządzanie jest słabiej ustrukturowane i mniej sformalizowane. „Europejczyk rozpoczynający pracę $\mathrm{w}$ USA będzie zaskoczony, odkrywszy, że istnieje zestaw gotowych, uprzednio przemyślanych odpowiedzi na prawie każde pytanie, Amerykanin oceni zarządzanie europejskie jako mniej ustrukturowane, mniej zdyscyplinowane i bardziej chaotyczne" 19 . W sferze realizacyjnej Europejczycy są znacznie mniej rygorystyczni od Amerykanów, ponieważ „nigdy nie oczekują, że kryteria przez nich postawione będą w stu procentach spełnione"20. Mamy tu zatem do czynienia z opozycją: uniwersalizm i intelektualizm po stronie Stanów Zjednoczonych oraz intuicjonizm i partykularyzm (doraźne reakcje) po stronie Europy.

18 Zob. A.F. Stoner, Ch. Wankel, Kierowanie, przeł. A. Ehrlich, PWE, Warszawa 1994.

${ }^{19}$ H. Bloom, R. Calori, Ph. de Woot, Zarządzanie europejskie, przeł. M. Jarosiński, POLTEXT, Warszawa 1996, s. 43.

${ }^{20}$ Ibidem, s. 93. 
Dość interesujące rezultaty przynosi zastosowanie metafory płciowej do porównawczej analizy kultur organizacyjnych. Jak przekonują Bloom, Calori i de Woot, na tle kultury amerykańskiej kultura europejska jest kulturą kobiecą. Uczestnicy tego kręgu kulturowego wysoko cenią poczucie bezpieczeństwa i stałość zatrudnienia, dobre stosunki ze współpracownikami, a zwłaszcza kierownikiem, skromność, nieokazywanie ambicji. Relatywnie niżej cenione są osiągnięcia, natomiast sympatię wzbudzają „nieudacznicy i antybohaterowie" 21 . Konflikty organizacyjne są raczej tłumione, praca nie jest najważniejszą wartością życiową i ustępuje miejsca rodzinie, panuje duży nacisk na egalitaryzm płacowy. Dla pracowników duże znaczenie ma przynależność grupowa, bliskie kontakty, od innych ludzi oczekuje się wsparcia i pomocy. Jednakże kobiece i męskie cechy kulturowe nie odnoszą się tylko do porównania Europa - Stany Zjednoczone, lecz mają wymiar ogólnoświatowy; także Europa jest pod tym względem dość wyraźnie zróżnicowana. Nie ulega wątpliwości, że polska kultura organizacyjna ma wyraźne cechy kobiece, a ich natężenie jest większe niż przeciętnie w Europie Zachodniej.

Zastanówmy się teraz, czy stwierdzony wcześniej podział Europy na dwa kręgi kulturowe: protestancki i katolicki, zachowuje swoją ważność. I tak na przykład autorzy książki o zarządzaniu europejskim zwracają uwagę na wyraźne różnice między krajami północnymi i łacińskimi. Podział ten jest paralelny do religijnego podziału Europy na kraje katolickie i protestanckie ${ }^{22}$. Z kolei w pracy Mole'a poświęconej zróżnicowaniu kultur organizacyjnych znajdziemy bardzo wiele argumentów na rzecz podobieństwa krajów katolickich Unii Europejskiej i ich odrębności od krajów protestanc$k i^{23}$. Dość ciekawe rezultaty uzyskano w efekcie badań nad menedżerami z trzydziestu krajów zajmującymi stanowiska wyższe niż średnie kierownicze, którzy w latach 1986-1993 uczestniczyli w ponad pięciuset seminariach organizowanych przez Centrum Studiów nad Międzynarodowym Biznesem w Holandii. Także i tutaj różnice $\mathrm{w}$ postawach można przypisać pochodzeniu z krajów o różnych doświadczeniach religijnych ${ }^{24}$. W polskich badaniach ankietowych ${ }^{25}$ zastosowano identyczne pytania, zaś odpowiedzi porównano z tymi, które uzyskali C. Hampden-Turner i A. Trompenaars. W polskich badaniach pod uwagę wzięto odpowiedzi respondentów zajmujących na

${ }^{21}$ G. Hofstede, op. cit., s. 149.

22 H. Bloom, R. Calori, Ph. de Woot, op. cit., s. 84.

${ }^{23}$ Zob. J. Mole, $W$ tyglu Europy. Wzorce i bariery kulturowe w przedsiębiorstwach, przeł. M. i T. Ronikier, Prószyński i S-ka, Warszawa 2000.

${ }^{24}$ Zob. C. Hampden-Turner, A. Trompenaars, Siedem kultur kapitalizmu, przeł. D. Gostyńska, Dom Wydawniczy ABC, Warszawa 1998.

${ }^{25}$ Dobór próby i założenia badawcze opisano w: J.T. Hryniewicz, op. cit., s. 15-18. 
tyle wysokie stanowiska kierownicze, że ich podwładni mają własnych kierowników. Warunek taki spełniało 160 osób. A oto rezultaty badań.

Tabele 1a-c. Polscy i zagraniczni kierownicy - zapotrzebowanie na afiliacyjność i kolektywizm

\section{Tabela 1a}

(a) Nowy pracownik musi przede wszystkim pasować do grupy, zespołu, w którym będzie pracować.

(b) Nowy pracownik musi przede wszystkim posiadać umiejętności, wiedzę i dowody sukcesów odniesione z poprzedniej pracy.

\begin{tabular}{|c|c|c|c|c|c|c|}
\hline \multicolumn{7}{|c|}{$\begin{array}{c}\text { Liczba odpowiedzi typu b } \\
\text { (w \%) }\end{array}$} \\
\hline $\begin{array}{c}\text { Stany Zjed- } \\
\text { noczone }\end{array}$ & Kanada & $\begin{array}{c}\text { Wielka } \\
\text { Brytania }\end{array}$ & Niemcy & Włochy & Francja & Polska \\
\hline 92 & 91 & 71 & 87 & 62 & 57 & 64 \\
\hline
\end{tabular}

\section{Tabela 1b}

Który z niżej wymienionych rodzajów pracy bardziej Panu/Pani odpowiada?

(a) Praca, w której ocenia się efekty wspólnych działań niezależnie od osobistego wkładu.

(b) Praca, w której ocenia się przede wszystkim indywidualną aktywność i osobiste zasługi.

\section{Liczba odpowiedzi typu b}

$(\mathbf{w} \%)$

\begin{tabular}{|c|c|c|c|c|c|c|}
\hline $\begin{array}{c}\text { Stany Zjed- } \\
\text { noczone }\end{array}$ & Kanada & $\begin{array}{c}\text { Wielka } \\
\text { Brytania }\end{array}$ & Niemcy & Włochy & Francja & Polska \\
\hline 97 & 96 & 90 & 84 & 69 & 69 & 63 \\
\hline
\end{tabular}

Tabela 1c

Kiedy lepiej wykonuje Pan/Pani swoją pracę?

(a) Gdy współpracownicy znają mnie osobiście i akceptują.

(b) Wystarcza, żeby współpracownicy szanowali moją pracę, nieważna jest ich akceptacja i przyjaźń.

\begin{tabular}{|c|c|c|c|c|c|c|}
\hline \multicolumn{7}{|c|}{$\begin{array}{c}\text { Liczba odpowiedzi typu a } \\
\text { (w \%) }\end{array}$} \\
\hline $\begin{array}{c}\text { Stany Zjed- } \\
\text { noczone }\end{array}$ & Kanada & $\begin{array}{c}\text { Wielka } \\
\text { Brytania }\end{array}$ & Niemcy & Włochy & Francja & Polska \\
\hline 18,0 & 12,5 & 24,1 & 27,1 & 33,6 & 24,6 & 64,4 \\
\hline
\end{tabular}

Źródło: rezultaty zagraniczne C. Hampden-Turner, A. Trompenaars, op. cit., s. 58, 219; dane polskie J.T. Hryniewicz, op. cit., s. 41-42. 
Postawy menedżerów amerykańskich (Stany Zjednoczone + Kanada) wyraźnie różnią się od postaw menedżerów europejskich - ci drudzy są bardziej kolektywistyczni i w większym stopniu oczekujący prestiżu oraz emocjonalnego poparcia. Postawy menedżerów europejskich z krajów katolickich i protestanckich są wyraźnie zróżnicowane, chociaż różnice te nie są tak duże jak między Europą a Ameryką. Menedżerowie z europejskich krajów protestanckich są mniej kolektywistyczni i mniej afiliacyjni. Postawy polskich kierowników są podobne do postaw kierowników z krajów katolickich, z tym jednak, że polscy kierownicy są bardziej kolektywistyczni niż menedżerowie z dwóch innych krajów katolickich. Natomiast tym, co rzuca się w oczy (zob. tabela 1c), jest drastycznie duże zapotrzebowanie polskich menedżerów na emocjonalne poparcie ze strony współpracowników. Widać wyraźnie, że są oni bardzo silnie emocjonalnie uzależnieni od otoczenia. Warto zauważyć, że podobnie odpowiadają na pytanie z tabeli 1c inni kierownicy, właściciele przedsiębiorstw i pozostali pracownicy z naszego kraju. Oznacza to, że emocjonalne uzależnienie od otoczenia dotyczy nie tylko kierowników, ale jest immanentną cechą polskiej kultury organizacyjnej.

Jedną z ważniejszych cech wschodnioeuropejskiej kultury organizacyjnej jest autokratyczny styl kierowania. Wynika to z międzynarodowych badań przeprowadzonych w krajach Europy Wschodniej i Zachodniej. Mianowicie, autokratyczny styl kierowania jest typowy dla polskich oraz czeskich kierowników i wyróżnia ich na tle kierowników ze Stanów Zjednoczonych, Francji, Austrii, Niemiec i Szwajcarii, którzy są w większym stopniu nastawieni na partycypację pracowniczą ${ }^{26}$. Jerzy Mączyński, podsumowując wspomniane wyżej międzynarodowe doświadczenia badawcze, stwierdza, że: „U nas powszechny jest model «idziemy na żywioł i jakoś to będzie» [...] menedżerowie z Polski, Czech, Włoch [...] dają odczuć swoim pracownikom «kto tu rządzi» [...] polscy menedżerowie nie lubią dzielić się władzą [...] koncentrują się na sobie, czemu dają wyraz, urządzając pełne przepychu gabinety i kupując bardzo drogie samochody. [...] Pozostał nam duży dystans, wręcz przepaść, która dzieli władców od ludu. [...] Nie lubimy tych, którzy nas się nie radzą, ale takich, którzy tak postępują, nie szanujemy. [...] U nas na linii przełożony - pracownik pojawia się lęk, a tam, gdzie jest strach, nie będzie kreatywności. [...] Zagraniczni menedżerowie w polskich firmach zachowują się tak, jak tego oczekują pracownicy, czyli są autokra-

26 Zob. J. Mączyński, Diagnozowanie partycypacji decyzyjnej, Wydawnictwo IFiS PAN, Warszawa 1998. 
tami. [...] Polki są bardziej partycypacyjne niż mężczyźni, mają wyższy wzgląd na podwładnych" 27 .

Analizę wspólnych cech wschodnioeuropejskiej kultury organizacyjnej w kategoriach dziedzictwa wzorów po gospodarce folwarcznej komplikuje fakt przynależności niektórych społeczeństw do bizantyńskiego kręgu kulturowego. W trakcie badań nad więzią społeczną, instytucjami i ich związkiem z samobójstwami Masaryk, a wcześniej Durkheim stwierdzili, że siła więzi społecznej rośnie wraz z przesuwaniem się od protestantyzmu, poprzez katolicyzm, do prawosławia. Specyfiką tego ostatniego jest podporządkowanie strażnika norm moralnych (Kościoła) państwu. Zastanówmy się, na ile kolektywizm prawosławny jest silniejszy na przykład od polskiego. Podstawą strukturalizacji społecznej są w Polsce grupy rodzinno-koleżeńskie, które kształtują orientacje wobec innych grup i instytucji. W efekcie osobnik dąży do tego, aby jego uczestnictwo w organizacji politycznej i ekonomicznej miało taki sam charakter jak w rodzinie: emocjonalne współbrzmienie, kontakty osobiste, prymat lojalności osobistej nad formalną, odrzucenie bezosobowości, matriarchat albo patriarchat wobec podwładnych itp. W latach dziewięćdziesiątych John Mole badał kulturę organizacyjną w Rosji. Oto synteza wniosków z jego badań: „Podstawową jednostką społeczną jest rozszerzona rodzina, powiększona o grono bliskich przyjaciół [...] panują tu oligarchie rodzinne [...] dzieci wybierają zawód uprawiany przez pokolenia ich przodków. Nadal trudno tu zostać dziennikarzem, jeżeli nie jest to zawód któregoś z rodziców, lub dyplomatą, o ile nie jest się dzieckiem dyplomaty"28. Komunistyczny system gospodarczy w Rosji mógł funkcjonować tylko „w oparciu o nieformalne siatki menedżerów i biurokratów, którzy wymieniali między sobą usługi i towary. [...] Teraz, po załamaniu się bardziej oficjalnych struktur owe rodziny stały się jeszcze ważniejsze" $^{29}$. Z badań nad przedsiębiorstwami prywatnymi, które prowadziłem we Włocławku, wynikało, iż wiele z nich zwiększyło obroty po 1990 roku, aby niedługo po tym zbankrutować. Stało się tak między innymi dlatego, że ich właściciele nie byli $\mathrm{w}$ stanie dokonać delegacji i zatrudnić ekspertów w tych sprawach, na których się nie znali. Podobnie jest w Rosji, gdzie „rosyjscy szefowie nie umieją jeszcze przekazywać części władzy swoim podwładnym" 30 .

27 A. Borowiec, Rozmowa z prof. dr. hab. Jerzym Mączyńskim o sposobie sprawowania funkcji przywódczych w różnych krajach, dodatek do "Gazety Wyborczej” "Gazeta - Praca” 24.03.2003.

28 J. Mole, op. cit., s. 246.

29 Ibidem, s. 251.

30 Ibidem, s. 257. 
Podobieństwo strukturalizacji społecznej Polski i Rosji jest zatem dość wyraźne. $Z$ drugiej jednak strony w Polsce stowarzyszenia ponadrodzinne mają większe znaczenie niż w Rosji i co za tym idzie, większe są tu też doświadczenia w zakresie bezosobowego uczestnictwa, co oznacza, że formalne wymogi i bezosobowe procedury są bardziej tolerowane i akceptowane. Na podstawie dotychczasowych analiz możemy przyjąć, iż wschodnioeuropejską kulturę organizacyjną wyróżnia relatywnie silniejszy niż na zachodzie Europy kolektywistyczny partykularyzm i personalizm, co oznacza, że bezosobowe reguły i indywidualne zobowiązania wobec abstrakcyjnych symboli, takich jak np. uczciwość czy prawda, dość często ustępują pierwszeństwa zobowiązaniom osobistym wobec członków własnych grup rodzinno-koleżeńskich. Potwierdzają to wyniki badań realizowanych przez D. Bartkowską-Nowak, która zastosowała technikę trzech pytań projekcyjnych do poznania sposobu rozstrzygnięcia dylematu: czy dać świadectwo prawdzie i narazić na straty przyjaciela, czy postąpić odwrotnie, a następnie porównała wyniki własnych badań $\mathrm{z}$ wynikami badań międzynarodowych Trompenaarsa i Hampden-Turnera. Okazało się, że polscy respondenci mniej więcej dwukrotnie rzadziej wybierali opcję wierności prawdzie niż na przykład respondenci w Stanach Zjednoczonych, Szwajcarii, Finlandii, Holandii czy Wielkiej Brytanii. Z kolei wyniki podobne do polskich uzyskano w Rosji, Serbii, Czechach i Bułgarii31.

\section{STAN PSYCHICZNY JAKO EFEKT HISTORII GOSPODARCZEJ I KULTUROWEJ ORAZ JEGO ZWIĄZEK Z ROZWOJEM GOSPODARCZYM}

Związek stanu psychicznego z rozwojem gospodarczym jest niezwykle złożony. Pewne jest tylko to, że istnieje. Natomiast nie jest oczywiste, na ile jest skutkiem, a na ile jedną z przyczyn tej bardzo pożądanej kategorii ekonomicznej. Gwoli ścisłości dodać należy, że spodziewamy się tu raczej zależności interakcyjnej niż przyczynowej, co należy rozumieć tak, iż zaspokojenie potrzeb pracowników zwiększa ich komfort psychiczny, a to owocuje bardziej wydajną pracą. Z kolei większa wydajność pracy skutkuje większymi możliwościami inwestowania w humanizowanie pracy, co wpływa na lepszy psychiczny komfort pracy itd. W trakcie swoich działań każdy pracownik wydatkuje energię psychiczną, czyli ponosi określony koszt pracy. Pracownik ponoszący duży psychiczny koszt pracy będzie się ograniczał do

31 D. Bartkowska-Nowak, Czy urzędy samorzadowe potrzebuja procedur kadrowych?, „Samorząd Terytorialny" 2001, nr 7-8, s. 92-93. 
tego, co konieczne, czyli do zachowań formalnych, i unikał przejawiania inicjatywy. W codziennych sytuacjach organizacyjnych pracownicy ponoszący duży psychiczny koszt pracy postrzegają rzeczywistość w taki sposób, aby móc uzasadnić swoją bierność. Z badań nad aktywną zawodowo ludnością trzynastu miast polskich oraz $\mathrm{z}$ badań przeprowadzonych w czternastu polskich przedsiębiorstwach wynika, że pracownicy różniący się poziomem ponoszonego psychicznego kosztu pracy odmiennie postrzegają te same sytuacje organizacyjne. Ci z nich, którzy ponoszą mały koszt psychiczny, są bardziej optymistyczni, bardziej nastawieni na samorealizację intelektualną i bardziej innowacyjni.

Koszt psychiczny wpływa na organizacje gospodarcze podobnie jak koszt finansowy, tyle że w innej sferze. Wysoki poziom psychicznych kosztów pracy $\mathrm{w}$ danym przedsiębiorstwie może prowadzić do tak silnej blokady i oporu przeciwko zmianom, że ich wprowadzenie jest niemożliwe bez znacznej wymiany pracowników i kierowników ${ }^{32}$. Związek kosztu psychicznego z rozwojem gospodarczym polega na tym, że im większy jest koszt psychiczny, tym mniej energii psychicznej może być przeznaczone na pracę i tym mniejsza jest jakość i ilość pracy. Frustracje i stresy doświadczane przez ludzi są zasadniczym czynnikiem zwiększającym dyskomfort psychiczny. Dyskomfort psychiczny jest zatem równoznaczny z ponoszeniem kosztu psychicznego. Im większy dyskomfort, tym większy koszt psychiczny. Praca jest jedną z wielu dziedzin aktywności życiowej i z tego względu "konkuruje” z innymi rodzajami aktywności o zasoby energii psychicznej. Wynika stąd prosty wniosek, że im większy jest dyskomfort psychiczny doświadczany $\mathrm{w}$ różnych sferach życia, tym mniej energii psychicznej może być przeznaczone na pracę, tym niższa jest jej ilość, jakość i innowacyjność.

Jak się to ma do porównań Wschodniej i Zachodniej Europy? W Europie Wschodniej mamy do czynienia z relatywnie silniejszym natężeniem czynników sprzyjających dyskomfortowi psychicznemu i niższym natężeniem czynników sprzyjających dobrostanowi psychicznemu. Z dość drobiazgowych analiz wielu równań regresji, dokonanych przez P. Bohnke, wynika, że najsilniejszą determinantą różnic narodowych wskaźników dobrostanu psychicznego jest bogactwo danego kraju mierzone produktem krajowym brutto na jednego mieszkańca i związany z tym poziom stopy życiowej. Drugim co do ważności czynnikiem jest społeczna integracja, czyli częstość kontaktów z innymi ludźmi, spoistość rodzin i dostępność pomocy ze strony innych ludzi w przypadku trudności życiowych. Natomiast trzecim czynni-

32 Zob. J.T. Hryniewicz, op. cit., s. 64-104. 
kiem sprawczym dobrego stanu psychicznego jest stan społeczeństwa, czyli ocena usług publicznych i szans zrealizowania aspiracji i potrzeb przez mieszkańców danego kraju33. Spośród tych czynników tylko jeden - integracja społeczna na poziomie rodzinnym - ma w krajach wschodnioeuropejskich relatywnie korzystny przebieg.

Dla oceny stanu psychicznego pracowników i kierowników wschodnioeuropejskich ważne znaczenie mają również opisane wcześniej zjawiska kulturowe. Realizowanie wzorów właściwych gospodarce rynkowej nie ma we wschodnioeuropejskich społeczeństwach spontanicznego charakteru. Wzory te są czymś odmiennym od utrwalonego rdzenia kulturowego. Są one wyuczone i ich stosowanie musi być poprzedzone aktem refleksji. Natomiast taki akt intelektualny dość często jest poprzedzony analizą krytyczną własnego dziedzictwa kulturowego i zachowań współrodaków pielęgnujących swoją tożsamość kulturową i narodową. W tym tkwi trudność przystosowania się takich krajów jak Polska do wyzwań gospodarki globalnej i opartej na wiedzy. Mieszkańcy krajów „przodujących w dziele globalizacji" są w znacznie lepszej sytuacji. Globalizacja opiera się na wzorach kulturowych wytworzonych w tych krajach. Dla ludzi ukształtowanych w owych kulturach dostosowanie się do globalizacji czy gospodarki opartej na wiedzy ma charakter kontynuacji dotychczasowego dziedzictwa kulturowego. Dostosowanie takie ma charakter o wiele bardziej spontaniczny, nie wymaga pogłębionej analizy otoczenia. Łączy się $\mathrm{z}$ wydatkowaniem relatywnie mniejszej ilości energii psychicznej i większym komfortem psychicznym. Natomiast w krajach importujących nowe wzory kulturowe zużywa się relatywnie więcej energii psychicznej na ich przyswojenie i nie wystarcza jej na wypracowanie innowacji oraz własnych poważnych propozycji rozwojowych. Załóżmy, że wskaźnikiem dobrostanu psychicznego jest zadowolenie z różnych aspektów życia. Mieszkańcy Europy Zachodniej są wyraźnie bardziej zadowoleni niż mieszkańcy Europy Wschodniej. Mianowicie, zadowolenie $\mathrm{z}$ mieszkania mierzone $\mathrm{w}$ skali od 1 do 10 wynosiło: w UE25 - 7,5, w Nowej Unii - 6,7, w Polsce - 6,5, na Litwie - 5,9, na Słowacji - 6,8, w Rumunii - 7,2, w Danii 8,4. Zadowolenie z wykształcenia: w UE25 - 6,9, w Nowej Unii - 6,4. Polska była tu na przedostatniej pozycji z punktacją 6,2, przed Turcją - 4,7. Niezadowolenie ze stanu zdrowia mierzone $w$ procentach: UE25 - 7,0, Cypr - 1, Włochy - 2, Dania, Francja, Grecja po 4, Łotwa, Litwa, Polska - po 19. Optymizm co do przyszłości, mierzony podobnie jak

33 P. Bohnke, First European Quality of Life Survey: Life Satisfaction, Happiness and Sense of Belonging, European Foundation for the Improvement of Living and Working Conditions, Dublin 2005, http://www.eurofound.europa.eu/pubdocs/2005/91/en/1/ef0591en.pdf, s. 89 i n. [dostęp: 15.06.2013]. 
w opisywanych tu badaniach, w krajach UE25 deklarowało $64 \%$ badanych. W krajach Nowej Unii 63\%, natomiast w Danii 93\%. Polska, z 68\% optymistów, zajmowała tu "dość dobre”, ósme miejsce od końca, wyprzedzając m.in. Francję - 45\%, Bułgarię - 49\% i Słowację 41\%. Jak widać, poziom zadowolenia życiowego Polaków jest nieznacznie niższy od przeciętnego w krajach wschodniej części Europy, natomiast optymizm wobec przyszłości jest nieco większy34.

W jednym z sondaży Europejczykom zadano pytanie o to, czy stan zdrowia fizycznego $\mathrm{w}$ ciągu ostatnich czterech tygodni był powodem tego, że osiągnęli w pracy lub innej regularnej aktywności mniej, niżby chcieli. Przeciętnie w Europie 54\% ludzi nie doświadczyło nigdy czegoś takiego, a $46 \%$ tak. W Polsce doświadczyło tego z różną intensywnością $58 \%$ respondentów, a $42 \%$ nigdy. Najzdrowsi wydają się mieszkańcy Luksemburga i Wielkiej Brytanii, z których aż 65\% nigdy nie doświadczyło takiego stanu rzeczy. Spośród krajów UE najmniej odporni są Słowacy - tylko 30\% nigdy $\mathrm{w}$ ciągu ostatnich czterech tygodni zdrowie nie przeszkadzało w pracy. Zaskakujące jest, że Włochom słabe zdrowie przeszkadza w pracy - tylko $42 \%$ deklaruje, iż tak nie jest, identycznie jak w przypadku Węgrów i Polaków. Jednak per saldo mieszkańcy krajów Europy Wschodniej nowo przyjętych do UE cechują się wyraźnie większymi problemami zdrowotnymi niż mieszkańcy krajów „starej Unii” ${ }^{35}$. Nie ulega wątpliwości, że świadomość tego, iż zdrowie przeszkadza w osiąganiu zamierzeń, nie może się nie odbić na psychice człowieka. W tych krajach, w których stan zdrowia daje się we znaki ich mieszkańcom, możemy oczekiwać znacznie większego dyskomfortu psychicznego niż tam, gdzie tak nie jest. W cytowanym wcześniej sondażu znalazło się także pytanie o to, czy jakieś problemy emocjonalne $\mathrm{w}$ ciągu ostatnich czterech tygodni były powodem tego, że osiągnięcia w pracy lub innej regularnej aktywności były mniejsze od oczekiwanych. Odpowiedzi "nigdy" udzieliło 61\% mieszkańców UE i np. 77\% mieszkańców Luksemburga. Na tym tle mieszkańcom krajów Europy Wschodniej emocje wyraźnie przeszkadzają w pracy. Relatywnie najgorzej jest pod tym względem na Słowacji, gdzie tylko 39\% udzieliło odpowiedzi "nigdy”, w Bułgarii - 42\% i w Polsce - 43\%. Wśród krajów „starej Unii” tylko Włochy i Austria uzyskały wskaźniki podobne do krajów Europy Wschodniej mieszczące się w przedziale 46-49\% (Litwa, Estonia, Węgry, Łotwa, Rosja) ${ }^{36}$. Problemy

${ }^{34}$ W. Keck, J. Delhey, WZB, Subjective Well-Being, [w:] Quality of Life in Europe, European Foundation for Improvement of Living and Working Conditions, 2004, s. 63-70, http://www. eurofound.europa.eu/pubdocs/2004/105/en/1/ef04105en.pdf [dostęp: 20.06.2013].

35 Eurobarometer, Mental Well-being, Special Eurobarometer, May 2006, s. 14.

36 Ibidem, s. 20. 
emocjonalne takie jak depresja czy niepokój mogą powodować między innymi skrócenie czasu poświęcanego na pracę lub inne czynności życiowe. W skali UE25 przytrafia się to $12 \%$ respondentów, ale w Polsce $19 \%$ i na Łotwie 20\%, natomiast w Irlandii, Austrii, Danii, Wielkiej Brytanii i Czechach 9-10\%. Czy niepokój i depresja powodują, że pracę wykonuje się mniej starannie? Odpowiedzi twierdzących średnio w UE jest 14\%, w Polsce, Grecji, na Łotwie i Litwie - 22-23\%. Podobnie mieszkańcy Europy Wschodniej relatywnie częściej deklarowali, że problemy emocjonalne i zdrowotne mają wpływ na ich aktywność społeczną, tj. spotkania ze znajomymi, krewnymi itp. Tak odpowiadali respondenci ze Słowacji, Litwy, Łotwy i Polski oraz z dwóch krajów "starej Unii”: Włoch i Austrii (od 47 do 56\%) ${ }^{37}$. Pytano także o bardziej szczegółowe problemy. I tak na przykład okazało się, że Włosi, Litwini, Polacy i Węgrzy są aż tak schorowani, że mają trudności z przesuwaniem stołu, operowaniem odkurzaczem i noszeniem zakupów 32-34\% odpowiedzi twierdzących ${ }^{38}$. I jak tu nie wierzyć w stereotypy, np. o dolce far niente. Jak widać, wyniki badań porównawczych są dość podobne do wyników badań nad kosztem psychicznym w polskich fabrykach. Im większe są napięcia psychiczne, tym mniejsza ilość i jakość pracy.

Za takim ujęciem przemawiają wyniki badań nad zadowoleniem z pracy. Jak jednak wiadomo, nie każde zadowolenie z pracy owocuje wysokim poziomem motywacji pracowniczych. Zgodnie z teorią Herzberga czynnikiem sprawczym motywacji do pracy jest taki rodzaj zadowolenia z pracy, który jest następstwem zaspokojenia potrzeb samorealizacyjnych. $W$ jednym z sondaży europejskich zadano między innymi pytania o to, czy praca daje dobre perspektywy rozwoju i awansu, czy kwalifikacje znajdują zastosowanie, czy pracownik ma wpływ na decyzje i czy praca jest dobrze płatna ${ }^{39}$. Uzyskane rezultaty przekształcono $\mathrm{w}$ syntetyczną zmienną zadowolenia z pracy. Zmienna ta daje możność przewidywania poziomu motywacji do pracy $w$ różnych krajach, a to dlatego, że użyte wskaźniki wykazują silny związek z czynnikami motywacyjnymi wskazanymi przez Herzberga. Intelektualny związek człowieka z pracą sprawia, iż traktuje on ją jak osobiste wyzwanie i jest skłonny zaangażować się w jej dobre wykonanie. Skutkuje to mniejszą koniecznością programowania i nadzorowania pracy, a także większą innowacyjnością pracowników. Różnice w poziomie zadowolenia $\mathrm{z}$ pracy $\mathrm{w}$ poszczególnych krajach nie są zbyt duże, niemniej poznawczo dość wartościowe. W tym przypadku różnice między „starą" i „nową" Unią są mniej widoczne i „przełamane” podziałem na północ i południe Europy.

\footnotetext{
37 Ibidem, s. 25, 27.

38 Ibidem, s. 5.

${ }^{39}$ Ibidem, s. 21-22.
} 
Najniższy poziom zadowolenia z pracy notujemy bowiem w krajach Europy Wschodniej oraz we Włoszech, w Grecji, Hiszpanii i Portugalii. Jak widać, są to kraje relatywnie mniej zaawansowane gospodarczo. Ponadto sytuują się one poniżej przeciętnego poziomu wskaźnika innowacyjności obliczonego dla dwudziestu pięciu krajów UE ${ }^{40}$. Oczywiście, nie należy z tego wyprowadzać wniosku, że niski poziom zadowolenia z pracy jest wyłącznym powodem niskiej wydajności pracy i małej innowacyjności. Zgodnie z wcześniejszym ustaleniem jest o wiele bardziej prawdopodobne, iż mamy tu do czynienia ze związkiem interakcyjnym. Trzeba też zaznaczyć, że dla rozwoju gospodarczego nieco ważniejsze są czynniki instytucjonalne i polityka gospodarcza.

Przestrzeń europejską różnicują dwa rodzaje podziałów: na kręgi kulturowe definiowane religijnie oraz na odmienne kompleksy gospodarcze. Omówiliśmy te różnice $\mathrm{w}$ przekrojach: katolickość versus protestanckość oraz zachodnioeuropejskość versus wschodnioeuropejskość. Współczesne badania porównawcze dowodzą trwałości podziałów religijno-kulturowych. Natomiast wpływ komunizmu na kształtowanie się kultury organizacyjnej był dostrzegalny, ale raczej wtórny wobec tradycji wschodnioeuropejskiego kompleksu gospodarczego. Relatywne zapóźnienie cywilizacyjne oraz niedopasowanie kultury organizacyjnej do wzorów gospodarki rynkowej wiąże się z relatywnie wyższym kosztem psychicznym ponoszonym przez mieszkańców Europy Wschodniej. Europejskie badania nad komfortem psychicznym zrealizowane w krajach UE dowodzą, że stan psychiczny mieszkańców „Nowej Unii” jest wyraźnie gorszy. Wyniki badań nad dyskomfortem psychicznym zostały odniesione do problemów związanych z pracą. Okazało się, że relatywnie duży dyskomfort psychiczny powoduje duże straty energii psychicznej i sprawia, że ilość i jakość pracy poszczególnych pracowników w Europie Wschodniej są niższe.

\section{BIBLIOGRAFIA}

Bartkowska-Nowak D., Czy urzędy samorządowe potrzebuja procedur kadrowych?, „Samorząd Terytorialny" 2001, nr 7-8.

Benedict R., Wzory kultury, przeł. J. Prokopiuk, PWN, Warszawa 1966.

Bloom H., Calori R., de Woot Ph., Zarządzanie europejskie, przeł. M. Jarosiński, POLTEXT, Warszawa 1996.

40 A. Olechnicka, Innowacyjność polskich regionów, [w:] Polska regionalna i lokalna w świetle badań EUROREG-u, red. G. Gorzelanka, Wydawnictwo Naukowe Scholar, Warszawa 2007, s. 65 . 
Bohnke P., First European Quality of Life Survey: Life Satisfaction, Happiness and Sense of Belonging, European Foundation for the Improvement of Living and Working Conditions, Dublin 2005, http://www.eurofound.europa.eu/pubdocs/2005/91/en/1/ ef0591en.pdf, s. 89 i n. [dostęp: 15.06.2013].

Boockmann H., Zakon Krzyżacki, przeł. R. Traba, Wydawnictwo MARABUT, Oficyna Wydawnicza VOLUMEN, Gdańsk-Warszawa 2002.

Borowiec A., Rozmowa z prof. dr. hab. Jerzym Mączyńskim o sposobie sprawowania funkcji przywódczych w różnych krajach, dodatek do "Gazety Wyborczej" "Gazeta - Praca” 24.03.2003.

Bystroń S., Kultura ludowa, Nasza Księgarnia, Warszawa 1936.

Durkheim É., Le suicide: étude de sociologie, PUF, Paris 1981.

Eisenga R., Felling A., Lammers J., Religious Affiliation, Income Stratification and Political Party Preference in Netherlands 1964 to 1992, "The Netherlands Journal of Social Sciences" 1994, vol. 30, no. 2.

Eurobarometer, Mental Well-being, Special Eurobarometer, May 2006.

Geremek B., Piesowicz K., Ludzie, towary, pieniądze, Wiedza Powszechna, Warszawa 1968.

Greeley A., Protestant and Catholic: Is the Analogical Imagination Extinct?, „American Sociological Review" 1989, no. 54(4).

Hampden-Turner Ch., Trompenaars A., Siedem kultur kapitalizmu, przeł. D. Gostyńska, Dom Wydawniczy ABC, Warszawa 1998.

Hofstede G., Kultury i organizacje, przeł. M. Durska, PWE, Warszawa 2000.

Hryniewicz J.T., Stosunki pracy w polskich organizacjach, Wydawnictwo Naukowe Scholar, Warszawa 2007.

Huntington S., Zderzenie cywilizacji i nowy kształt ładu światowego, przeł. H. Jankowska, MUZA SA, Warszawa 1997.

Keck W., Delhey J., WZB, Subjective Well-Being, [w:] Quality of Life in Europe, European Foundation for Improvement of Living and Working Conditions, 2004, http://www. eurofound.europa.eu/pubdocs/2004/105/en/1/ef04105en.pdf [dostęp: 20.06.2013].

Kłoczowski J., Młodsza Europa, PIW, Warszawa 1998.

Kłoskowska A., Socjologia kultury, PWN, Warszawa 1983.

Konrad G., Szelenyi I., The Intellectuals on the Road to Class Power, New York-London 1979.

Le Goff J., Kultura średniowiecznej Europy, przeł. H. Szumańska-Grossowa, Oficyna Wydawnicza VOLUMEN, Dom Księgarsko-Wydawniczy KLON, Warszawa 1994.

Mączyński J., Diagnozowanie partycypacji decyzyjnej, Wydawnictwo IFiS PAN, Warszawa 1998.

Mole J., W tyglu Europy. Wzorce i bariery kulturowe w przedsiębiorstwach, przeł. M. i T. Ronikier, Prószyński i S-ka, Warszawa 2000.

Morawski W., Socjologia ekonomiczna, Wydawnictwo Naukowe PWN, Warszawa 2001.

Olechnicka A., Innowacyjność polskich regionów, [w:] Polska regionalna i lokalna w świetle badań EUROREG-u, red. G. Gorzelanka, Wydawnictwo Naukowe Scholar, Warszawa 2007.

Parsons T., The Social System, Free Press, New York 1951.

Rutkowski J., Wieś europejska późnego feudalizmu (XVI-XVIII w.), wybór i wstęp J. Topolski, PIW, Warszawa 1986.

Stoner A.F., Wankel Ch., Kierowanie, przeł. A. Ehrlich, PWE, Warszawa 1994.

Tracy D., Analogical Imagination, The Crossroad Publishing Company, New York 1982.

Znaniecki F., Nauki o kulturze, PWN, Warszawa 1971. 